\title{
Critical Gaps in Land Governance with Respect to the Land Registration System in Ethiopia
}

\author{
Melkamu Belachew Moges *
}

\begin{abstract}
Land registration is a useful land information system practised in almost all modern nations. It is also true that many land registration systems fail due to a number of reasons. This article investigates whether the land registration system in Ethiopia has given due attention to sound land governance components which are critical for the success of any land registration system. Doctrinal and content analysis of legislative documents of Ethiopia is applied to this end. Desk review of relevant secondary material was also used. The article discusses the general role of good governance in such systems and shows the benefits of a land registration system that is exercised under good governance. A conceptual framework is used by which the land registration governance system of Ethiopia is weighed. I argue that the land registration system of Ethiopia has major gaps of land governance. Good land governance in land registration of the country could be enhanced by the provision of adequate legislative and policy framework, effective land registration institutional organs and efficient processes for the enforcement of the system.
\end{abstract}

\section{Key terms:}

Land registration $\cdot$ Land governance $\cdot$ Good governance $\cdot$ Ethiopia

\section{DOI http://dx.doi.org/10.4314/mlr.v15i2.4}

This article is licensed under a Creative Commons Attribution-NonCommercialNoDerivs (CC BY-NC-ND)

Received: 29 May 2021

Accepted: 18 November 2021

\section{Suggested citation:}

Melkamu Belachew Moges (2021), 'Critical Gaps in Land Governance with Respect to the Land Registration System in Ethiopia', 15(2) Mizan Law Re view: 419-454

\footnotetext{
* Melkamu Belachew Moges, LLB (AAU), MSc (KTH), PhD in Law (UniMelb), LL.D. Hon. (Commonwealth Uni.), Graduate Certificate (UniMelb).

Email: melkgrowthf@gmail.com

ORCID https://orcid.org/0000-0001-6605-5344
} 


\section{Contents}

Abstract

1. Introduction

2. The Critical Role of Good Land Governance in Land Administration

2.1 Components of good land governance

2.2 The relationship between land governance and land administration systems

2.3 Potential benefits of land registration systems under good governance

3. Evaluating Land Registration Governance in Ethiopia: Towards a Conceptual Framework

4. Governance of the Land Registration System in Ethiopia

4.1 Legislative framework for the land registration system

4.2 Practical enforcement of the land registration system

4.2.1 Setting land registration in motion

4.2.2 System quality assurance and compliance mechanisms

5. Salient Land Governance Gaps in Ethiopia's Land Registration System

6. Concluding Remarks

\section{Introduction}

Generally, in Ethiopia, like much of Africa, land administration in general and land registration in particular is based on rudimentary and informal practices rather than formal institutions. However, Ethiopia has undertaken a massive systematic rural land certification (a variant of land registration) since 1998 successfully covering a large part of the country which exceeds 50 percent. ${ }^{1}$ More than 25 million parcels have been registered in the rural

\footnotetext{
Frequenly used Acronyms

ANRS Amhara National Regional State

ARLAU P Amhara (Regional State Revised) Rural Land Administration and Use Determination Proclamation

FRLAUP (Federal) Rural Land Administration and Land Use Proclamation

FULRP (Federal) Urban Landholding Registration Proclamation

LGAF Land Governance Assessment Framework

SNNPR Southern Nations, Nationalities, and Peoples' Region

${ }^{1}$ Frank Byamugisha (2016), Transforming Africa's Agriculture Securing Land Tenure and Easing Access to Land, Background Paper for African Transformation Report 16 (Joint research between African Center for Economic Transformation (ACET) and Japan International Cooperation Agency Research institute (JICA-RI), p. 1.
} 
Critical Gaps in Land Governance with Respect to the Land Registration System... 421

areas of the country at an impressive scale, pace, and cost-effectiveness. The issuance of land certificates began in the region of Tigray in 1998, followed by ANRS in $2002^{2}$, and Oromia and the Southern Nations Nationalities and Peoples Region in subsequent years. ${ }^{3}$ Research shows that a 'Primary Book of Land Holding' was issued to almost all land holders in these regions under the first phase of land certification program. ${ }^{4}$

Following this, the Government has been in the process of undertaking the second level certification which involves extensive surveying, boundary demarcation and, potentially, the use of modern ICT technology. This would result in the issuance of "Secondary Book of Land Holding". The establishment of an efficient land administration system was one of the targets in the First Growth and Transformation Plan (GTP I) ${ }^{5}$ and subsequent related strategies. Pilot second-level land certification process was implemented in Tigray, Amhara, Oromia and Southern Nations, Nationalities, and Peoples' Region ('SNNP') from 2005 to $2013 .{ }^{6}$

Concerning the coverage of the second level certificates in Ethiopia, Gizachew et al indicated that $27 \%$ of the surveyed and adjudicated parcels

${ }^{2}$ Felix M. Muchomba (2017), 'Women's Land Tenure Security and Household Human Capital: Evidence from Ethiopia's Land Certification', World Dev., Vol. 98, pp. 310, 313.

${ }^{3}$ Id., p. 313; Berhanu Adenew and Fayera Abdi (2005), Land Registration in Amhara Region, Ethiopia (Research Report 3, Central Research Department of the UK's Department for International Development), p.10.

${ }^{4}$ Lauren Persha, Adi Greif and Heather Huntington (2017), Assessing the Impact of Second-Level Land Certification in Ethiopia (Paper prepared for presentation at the "2017 World Bank Conference on Land and Poverty" The World Bank -Washington DC, March 20-24, 2017), p. 5; Muchomba, supra note 2, p. 313 (citations omitted). In Ethiopia the land certification has been undertaken in two phases. The first phase is called Primary Book of Holding or $1^{\text {st }}$ level certification that involved the demarcation of parcels and issuance of holding certificates based on customary surveying methods and less modern registration system without maps. The second phase is called Secondary Book of Holding or $2^{\text {nd }}$ level certification that involves more advanced surveying and registration methods and certificates of holding. See Shewakena Aytenfisu Abab (2007), An Assessment of Rural Land Registration and Land Information System in Amhara Region, Ethiopia: a Land Administration Perspective (unpublished MSc thesis, the Royal Institute of Technology, Department of Real estate Planning and Land Law, Sweden), pp. 29-31.

${ }^{5}$ Ministry of Finance and Economic Development (MOFED), (2010). The Federal Democratic Republic of Ethiopia Growth and Transformation Plan (GTP) 2010/11-2014/15, Addis Ababa.

${ }^{6}$ Persha, Greif and Huntington, supra note 4, p. 3. 
were provided with second level certificates by $2015 .^{7}$ It can be observed that these attempts are meant to introduce relatively modern form of land management system with improved tenure security in the country through creating improved institutional and legislative mechanism for the system. In other words, the aim is to enhance a formal land administration system.

With respect to urban lands too, Ethiopia has included its aspiration of urban land registration development in the urban land development and management policy and its strategic plans. For instance, within the framework of GTP II (2016-2020), adjudication and registration of 1.6 million and 1.2 million landholdings respectively across 91 cities were planned in five years. ${ }^{8}$ Similarly, it is targeted to increase the performance of land registration services in the urban centers from 3\% to $60 \%$ from 2021 to $2030 .{ }^{9}$

These policies aspire to introduce an efficient and well-functioning cadastral system with the view to make urban land a driving force for political, social, economic, and environmental transformation. ${ }^{10}$ The Urban Landholding Registration Proclamation together with a set of regulations, directives, and manuals, have been adopted to govern the adjudication and registration of urban land held in line with the urban lands lease law. ${ }^{11}$ The overall objective of the urban cadastral system is to accelerate the socioeconomic and environmental development of urban centers by ensuring land holders' security of holding and recognition of title to immovable property. ${ }^{12}$

A land registration system as a tool for formal property system can yield positive fruits to the society only if it is carried out under appropriate conditions. ${ }^{13}$ Fulfillment of good (land) governance conditions is one of the

${ }^{7}$ Gizachew Abebe, Tigistu Gebremeskel and Rohan Bennett (2015), Implementation Challenges of the Rural Land Administration System in Ethiopia: Issues for Land Certification and the Information System (Paper prepared for presentation at the 2015 World Bank Conference on Land and Poverty, Washington DC, March 23-27, 2015), p.16.

${ }^{8}$ Solomon Dargie Chekole, Walter Timo de Vries and Gebeyehu Belay Shibeshi (2020), 'An Evaluation Framework for Urban Cadastral System Policy in Ethiopia', Land, Vol. 9, Issue 60, p.8.

${ }^{9}$ Federal Democratic Republic of Ethiopia Planning and Development Commission,

Ten year's Development Plan a Pathway to Prosperity 2021-2030, p. 48.

${ }^{10}$ Solomon, supra note 8.

${ }^{11}$ Urban Landholding Registration Proclamation, 2014, Proc. No. 818/2014, Fed. Neg. Gaz., Year 20, No.25 (hereinafter 'FULRP').

${ }^{12}$ Solomon, Supra note 8, p.8.

13 Melkamu Belachew (2015), Modelling Legislation for a Sustainable Cadastral System, Ch. 4 (PhD thesis, University of Melbourne, Melbourne Law School), pp. 78- 
Critical Gaps in Land Governance with Respect to the Land Registration System... 423

essential requirements for the success of a cadastral system. ${ }^{14}$ This article examines the gaps in the governance of land registration system put in place in Ethiopia. This will be carried out based on the conceptual framework formulated based on some universally accepted features of good land governance and some specific indicators of good land governance from the Land Governance Assessment Framework ('LGAF'). ${ }^{15}$

\section{The Critical Role of Good Land Governance in Land Administration}

\subsection{Components of good land governance}

The question of addressing good governance within land administration is increasingly becoming key in the land sector among development professionals, policy makers and academics. ${ }^{16}$ Good governance is an aspect of governance and government. "Government" is generally considered to be the exercise of control, power, or authority over a state in which land or territory is a central component. ${ }^{17}$ Governance is defined as 'the set of traditions and institutions by which authority in a country is exercised' which includes the process by which governments are selected, monitored and replaced; the capacity of the government to effectively formulate and implement policies (including land policy); and the respect of citizens and the state. $^{18}$

A more widely applicable definition is that governance is the process of decision-making and the process by which decisions are implemented and power is exercised by governments in managing a country's social,

102; See also: Klaus Deininger \& Hans Binswanger (1999), 'The Evolution of the World Bank's Land Policy: Principles, Experience, and Future Challenges', The World Bank Research Observer, No. 34, pp. 258-259; Joseph Blocher (2006), 'Building on Custom: Land Tenure Policy and Economic Development in Ghana', Yale Human Rights \& Development Law Journal, Vol.9, pp. 166, 176.

${ }^{14}$ See Melkamu, supra note 13, pp. 78-102.

15 See generally Klaus Deininger, Harris Selod, and Anthony Burns (2012), The Land Governance Assessment Framework Identifying and Monitoring Good Practice in the Land Sector).

${ }^{16}$ Tony Burns and Kate Dalrymple (2008), Conceptual Framework for Governance in Land Administration (FIG Working Week in Stockholm, Sweden).

${ }^{17}$ Keith C. Bell (2007), Good Governance in Land Administration (FIG Working Week Hong Kong, China SAR, May 13-17, 2007), p.7.

${ }^{18}$ Burns \& Darlymple, supra note 16, p.4 (citation omitted). 
economic, and spatial resources. ${ }^{19}$ Governance involves an analysis of both formal and informal actors involved in decision-making and the formal and informal structures that have been set in place to arrive at and implement the decision. ${ }^{20}$

It is even more difficult to define 'good governance'. ${ }^{21}$ Further, good or bad land governance is not an absolute condition; rather, there is a continuum between the two. ${ }^{22}$ Governance is qualified as 'good' when it adheres to certain interdependent principles. ${ }^{23}$ Some of the commonly identified key principles of good governance for land administration are efficiency; effectiveness; transparency, consistency and predictability; integrity and accountability; subsidiarity, autonomy and depoliticisation; civic engagement and public participation; equity, fairness and impartiality; and legal security and rule of law. ${ }^{24}$

The principle of efficiency implies that the procedure to register property transactions should be short and simple. The principle of effectiveness stresses the importance of capacity building and financial provision, as well as sound general socio-political conditions, such as political will and commitment, the rule of law, regulatory quality and political stability. The principles of transparency, consistency and predictability refer to the transparent recruitment of staff and transparent service standards and costs of services which will contribute to increased efficiency, accountability, fairness and confidence in agency integrity.

The principles of integrity and accountability dictate the application of uniform service standards, codes of conduct for staff (as well as mechanisms of sanction) and incentives such as awards. The principles of subsidiarity, autonomy and depoliticisation refer to increasing the autonomy of local land administration while introducing checks and balances at the national level to improve services and fight corruption. The principles of civic engagement

${ }^{19}$ Ibid.

${ }^{20}$ Id., p. 5.

${ }^{21}$ Id., p.4.

${ }^{22}$ UN-Habitat (2016), Fit-for-Purpose Land Administration Guiding Principles for Country Implementation, Report 2, p.65.

${ }^{23}$ Simon Hull \&Jennifer Whittal (2013) 'Good e-Governance and Cadastral Innovation: In Pursuit of a Definition of e-Cadastral Systems', South African Journal of Geomatics, Vol. 2, No. 4, p. 345 (citations omitted).

24 W Zakout, B Wehrmann and M Torhonen (2007), Good Governance in Land Administration: Principles and Good Practices (World Bank and FAO,) cited in Bell, supra note 17, p. 12. 
Critical Gaps in Land Governance with Respect to the Land Registration System... 425

and public participation imply improved access to information which would help achieve client orientation and responsiveness in land administration.

The principles of equity, fairness and impartiality require that all people should have the same access to service and receive the same service standards without any distinction based on political, economic status or any other factor. And finally, the principles of legal security and rule of law refer to a consistent, coherent, and legitimate legal framework and institutions as well as a fair and transparent judiciary to protect property rights. Those in power must have got the right to govern, have assumed their power through democratic processes, and can be replaced if the citizens are dissatisfied with them. ${ }^{25}$

Land governance is a system of governance with respect to just one basic aspect of socio-economic life, i.e., land. 'Land governance cannot be separated from governance of other sectors' ${ }^{26}$ In particular, land governance can be loosely defined as:

the range of political, organizational and administrative processes through which communities articulate their interests, their input is absorbed, decisions are made and implemented, and decision makers are held accountable in the administration, development and management of land rights and resources and the delivery of land services. ${ }^{27}$

So, land governance is about the policies, processes and institutions (formal or informal) by which decisions about land are made. This includes decisions on access to land, land rights, land use, and land development and determining and implementing sustainable land policies. ${ }^{28}$ Working to achieve good land governance or administration is also one way in which a society can improve its governance system and its commitment to democracy, the rule of law and human rights. ${ }^{29}$

In particular, good governance in land registration systems implies the prevalence of capable enforcement institutions. When the state fails to

${ }^{25}$ FAO (2007), Good Governance in Land Tenure and Administration. Land Tenure Series No. 9, Rome, p. 9.

${ }^{26} \mathrm{UN}-$ Habitat, supra note 22, p. 65.

${ }^{27}$ Burns \& Darlymple, supra note 16, pp. 4-5.

${ }^{28}$ Enemark, S. (2009) Facing the Global Challenges: the Importance of Land Governance and the Significance of the Cadastre (Proceedings of FIG Commission 7 One-day International Open Symposium "Progressing Towards u-Cadastre"), p.3.

${ }^{29} \mathrm{UN}-$ Habitat, supra note 22, p. 65. 
enforce property rights, "a variety of non-state actors define and enforce" them. ${ }^{30}$ Hence capacity development becomes a critical component of good governments. The United Nations Development Programme and the Organization for Economic Cooperation and Development provide the definition of capacity development as:

the process by which individuals, groups, organizations, institutions and societies increase their abilities to: perform core functions, solve problems, and define and achieve objectives; to understand and deal with their development needs in a broader context and in a sustainable manner. ${ }^{31}$

The success of a land registration system 'will depend on the quality, character and capacity of the state'. ${ }^{32}$ Deininger and Feder stress that 'without institutions to enforce property rights effectively, the rights presumably protected by the land registry may exist only on paper and have little practical value'. ${ }^{33}$ That is, '[a] property right that is not enforced does not exist' ${ }^{34}$ Capacity, at least in the context of Third World countries, also involves the development of cultures and attitudes to better way of lives, and envisages the requisite level of effectiveness and competence of the enforcement institutions, namely, the authorities and agencies which administer land registration and dispute resolution systems. ${ }^{35}$

${ }^{30}$ Sandra F Joireman (2011), Where There is No Government: Enforcing Property

Rights in Common Law Africa (Oxford University Press), p. 5.

31 Stig Enemark (2005), Supporting Capacity Development for Sustainable Land Administration Infrastructures (Paper presented at the Eighth United Nations Regional Cartographic Conference for the Americas (UNRCCA), New York), p. 5 (citation omitted).

${ }^{32}$ Peter Larmour (2002), 'Policy Transfer and Reversal: Customary Land Registration from Africa to Melanesia', Public Administration \& Development, Vol. 22, p. 160; See also Daniel Fitzpatrick (2006), 'Evolution and Chaos in Property Rights Systems: The Third World Tragedy of Contested Access', The Yale Law Journal, Vol. 115, p. 1000; Robert T Deacon (1994), 'Deforestation and the Rule of Law in a CrossSection of Countries', Land Economics, Vol. 70, p. 414.

${ }^{33}$ Klaus Deininger and Gershon Feder (2009), 'Land Registration, Governance, and Development: Evidence and Implications for Policy', The World Bank Research Observer, Vol. 24, p. 239.

34 Joireman, supra note 30.

${ }^{35}$ Roman Krznaric (2006), 'The Limits on Pro-poor Agricultural Trade in Guatemala: Land, Labour and Political Power', Journal of Human Development, Vol. 7, p. 132. 
Critical Gaps in Land Governance with Respect to the Land Registration System... 427

\subsection{The relationship between land governance and land administration systems}

Measures of good governance and measures of land administration reform have largely developed separately. ${ }^{36}$ In particular, the question of good land governance is relatively a new idea. ${ }^{37}$ However, the momentum for incorporating good governance in the development agenda and within land administration reform strategies has been building over the past two decades highlighting its importance to socially and economically responsible sustainable development. ${ }^{38}$

Conceptually and operationally, there is a strong link between the concepts of good land governance and land administration. As discussed earlier, sound land governance requires a legal and regulatory framework, operational processes and capacity to implement land policies and land management strategies consistently within a jurisdiction or country in sustainable ways. The land management paradigm developed by Enemark et al helps us to best understand this interrelationship. ${ }^{39}$ The Paradigm illustrates that the land management activities may be described by three components, namely, land policies, land information infrastructures, and land administration infrastructures which underpin sustainable development. ${ }^{40}$ It further indicates that the land management activities are run by institutions and organisations whose arrangements and structures differ from one jurisdiction to the other and which may change over time. ${ }^{41}$ Land governance therefore involves land management, land administration, land law and policy, land registration systems (commonly denoted by the words, 'cadastre' and 'land register') and land tenure.

These key terms need careful understanding so that their salient features and the nexus between them can be carefully identified. Land management, a concept broader than land administration, is the process by which the

\footnotetext{
${ }^{36}$ Burns \& Darlymple, supra note 16, p.1.

${ }^{37}$ Robin Palmer (2007), Literature Review of Governance and Secure Access to Land, $\mathrm{p}$. 10.

${ }^{38}$ Burns \& Darlymple, supra note 16, p.3.

${ }^{39}$ Stig Enemark (2005), Understanding the Land Management Paradigm (FIG Com 7

Symposium on Innovative Technologies for Land Administration 19-25 June, Madison, Wisconsin, USA).

${ }^{40}$ Id., p. 3.

${ }^{41}$ Ibid.
} 
resources of land are put into good effect. ${ }^{42}$ Land management encompasses all activities associated with the management of land and natural resources that are required to achieve sustainable development. Sound land management is the operational process which is the tool for implementing land policies in comprehensive and sustainable ways.

Land administration is the operational component of the land management paradigm. It is about the relationship between people, places and rights, and the policies, institutions and legal regulations that govern this relationship. It includes the range of functions that ensure proper management of rights, restrictions, responsibilities and risks in relation to land, namely, land tenure, land value, land use planning, and land development (implementing utilities, infrastructure and construction planning). Land administration determines the processes of recording and disseminating information about each of these functions with respect to land and its associated resources when implementing land management policies. ${ }^{43}$ In this regard, land administration sits within the principles of responsible land governance and the overall framework of national land policies.

Land policy is part of the national policy on promoting objectives including economic development, social justice and equity, and political stability. Land policies may be associated with: security of tenure; land markets (particularly land transactions and access to credit); real property taxation; sustainable management and control of land use, natural resources and the environment; the provision of land for the poor, ethnic minorities and women; and measures to prevent land speculation and to manage land disputes.

Land laws are a set of instruments which are designed in various forms in order to authoritatively prescribe the types of rights and duties persons have with respect to land and associated natural resources, the types of enforcement institutions of the rules, and the mechanisms of getting redress in times of violation of the rights, restrictions, and obligations in land. The functions of a land registration system will be best served by legislation that meets certain criteria or principles. ${ }^{44}$ As Deininger and Binswanger note,

${ }^{42}$ United Nations-Economic Commission for Europe, Geneva (1996) Land Administration Guidelines with Special Reference to Countries in Transition ECE/HBP/96 (United Nations), p. 13.

${ }^{43}$ Id., p. 14.

${ }^{44}$ Fuller has coined eight excellences of the law which, according to him, a legal system needs to possess or exhibit as a minimal amount of respect and dignity for those affected by it and which, together, give the law its existence. These are generality of 
Critical Gaps in Land Governance with Respect to the Land Registration System... 429

'titling process requires a clear legal basis and a streamlined institutional infrastructure that is capable of administering the process efficiently. ${ }^{45}$ There are ample evidences that strengthen the claim that land registration systems need to be accompanied by appropriate legislation. Thus, Manji notes 'in Eastern Europe, South America, Asia and sub-Saharan Africa, the rule of law is seen as the cure for perceived economic and political ills. ${ }^{46}$

Cadastre is normally a parcel based, and up-to-date land information system containing [a] record of interests in land and which usually includes a geometric description of the location of land parcels describing the nature of the interests, the ownership or control of those interests, and often the value of the parcel and its improvements. ${ }^{47}$ Land register is a process of official recording of rights in land through deeds or as title on properties concerning changes in the legal situation of defined units of land. ${ }^{48}$ Land tenure and property rights refer to the relationship among people, as individuals or groups, with respect to land or property and the exclusive right to use land, enjoy the yield from land and improvements, and the right to transfer the land to another person. ${ }^{49}$

law, promulgation, prospectivity, clarity, consistency or coherence, possibility, constancy, and congruence between official action and declared rule. See generally Lon Fuller (1969), The Morality of Law, Rev. Ed. (New Haven: Yale University Press), pp. 46-91.

${ }^{45}$ Deininger \& Binswanger, supra note 13, p. 260. See also Malcolm Park (2003), The Effect of Adverse Possession on Part of a Registered Title Land Parcel (University of Melbourne, PhD Thesis,), p. 36.

${ }^{46}$ Ambreena Manji (2006). The Politics of Land Reform in Africa: From Communal Tenure to Free Markets (Zed Books), p. 52.

${ }^{47}$ The International Federation of Surveyors (FIG) (1995), FIG Statement on the Cadastre (Pub. No 11).

48 Jo Henssen, 'Basic Principles of the Main Cadastral Systems in the World' (Paper presented at Annual Meeting of Commission 7, Cadastre and Rural Land Management, the International Federation of Surveyors (FIG), Delft, The Netherlands, May 16, 1995) quoted in Jürg Kaufmann and Daniel Steudler, Cadastre 2014: A Vision for a Future Cadastral System (International Federation of Surveyors (FIG), 1998) 13.

${ }^{49}$ FAO, Land Tenure and Rural Development, FAO Land Tenure Studies 3 (FAO, 2002) 7; FIG, supra note 47, No 5. 


\subsection{Potential benefits of land registration systems under good governance}

As indicated above, land registration systems consist of data about land, persons and interests. ${ }^{50}$ The idea that land registration systems are critically important for any society -irrespective of the nature of land tenure systemis well-settled. ${ }^{51}$ In fact, the advantages of the system are not questioned at all, especially in the developed world; the challenge is always how to maintain the existing system in line with the fast changing needs of society especially the increasing needs of sustainable development.

For example, Kjellson had compared the US public cadastral system with that of Australia and Western Europe, and found out that it entailed a cost of $\$ 20$ billion annually. ${ }^{52}$ Similarly according to Wadhwa, India loses 1.3 per cent economic growth annually as a result of disputed land titles. ${ }^{53} \mathrm{In}$ Thailand, 'land improvements have been greater, land values are higher, there are improved credit and borrowing patterns by Thai farmers, and outputs and inputs per unit of land have been higher for the titled land than the untitled land'. ${ }^{54}$

Some of the commonly known advantages of land registration systems are the enhancement of security of land tenure, credit, investment and productivity, bolster property market, facilitate revenue collection from land, manage land disputes and conflicts, support land policy, land management

${ }^{50}$ FIG, supra note 47.

${ }^{51}$ De Soto has made an authoritative argument in favour of formalisation (cadastral systems). Hernando de Soto (2000), The Mystery of Capital: Why Capitalism Triumphs in the West and Fails Everywhere else (Black Swan). Also see United Nations-Economic Commission for Europe Working Party on Land Administration (2005), Social and Economic Benefits of Good Land Administration (HM Land Registry, 2nd ed,) 6; United Nations-Economic Commission for Europe (2005), Land Administration in the UNECE Region: Development Trends and Main Principles ECE/HBP/140 (United Nations,) 64; United Nations-Economic Commission for Europe, Geneva (1996), supra note 42, p. 7.

${ }^{52}$ Bengt Kjellson (2002). What Do Americans Pay for Not having a Public Land Rights Information System? (Paper presented at FIG Congress, Washington D C).

53 See D C Wadhwa (2002), "Guaranteeing Title to Land" Economic and Political Weekly, Vol. 37, p. 4699.

${ }^{54}$ Milt Reimers (2009-2010), “'Stuck in No Man's Land”: How Developing Countries Can Allocate Property Rights as a Means to Improve Their Citizens' Welfare and Grow Their Economies' Loyola Journal of Public Interest Law, Vol.11, 15-6 (citations omitted). 
Critical Gaps in Land Governance with Respect to the Land Registration System... 431

and land administration, and help land use planning. ${ }^{55}$ These specific advantages of land registration systems could be said to be ultimately fostering sustainable development in the broadest sense. ${ }^{56}$

A cadastral system as a tool for formal property system, however, benefits society if it is carried out under appropriate conditions. ${ }^{57}$ Fulfillment of good (land) governance conditions is one of the essential requirements for the success of a cadastral system. ${ }^{58}$ This is because good governance has a critical role in terms of establishing successful land administration systems. ${ }^{59}$ To begin with, land administration systems are components of a public infrastructure, and are provided by government. Indeed, a governmental structure that is responsible and accountable and which respects the fundamental rights of its own people can effectively provide this critical service.

It is a well-settled fact that democracies generally provide by far better property rights than other forms of governance such as autocracy and dictatorship. ${ }^{60}$ On the other hand, democratic government can exist only if it is elected by the people to whom the land registration is set. Only a government that assumes power under the well-known democratic channels can clearly define land rights and effectively enforce them thereby serving the people fairly.

${ }^{55}$ See e.g., Kaufmann, J. and Steudler, D. (1998), Cadastre 2014 - A Vision for a Future Cadastral System (FIG Commission 7, Switzerland); See also, Lemmen, C. et.al, (2005), A Vision on the Development of the Urban Cadastre in Egypt.; FIG-UN (1999), Bathurst Declaration on Land Tenure and Cadastral Infrastructures for Sustainable Development (Bathrust, Australia); FIG, supra note 47.

${ }^{56}$ Kaufmann and Steudler, supra note 55, p. 30.

${ }^{57}$ Supra note 13

${ }^{58}$ See Melkamu, supra note 13, pp. 78-102.

${ }^{59}$ Daron Acemoglu and James A Robinson (2012), Why Nations Fail: the Origins of Power, Prosperity, and Poverty (Crown Business New York, 1st ed) Ch 13; See also Helen McFarlane (2010), 'How Live Aid Got It Wrong: Land Law's Solution to Third World Poverty' Galway Student Law Review, Vol. 4, pp.74, 80; See also Gani Aldashev (2009), 'Legal Institutions, Political Economy, and Development' Oxford Review of Economic Policy, Vol. 25, pp. 257, 266; Michael Ochieng Odhiambo (2006), Improving Tenure Security for the Rural Poor Kenya, Tanzania and UgandaCase Study (FAO), p. v; F G Snyder (1980), 'Law and Development in the Light of Dependency Theory' Law and Society Review, Vol. 14, p. 723 cited in Kevin E Davis and Michael J Trebilcock (2001), 'Legal Reforms and Development' Third World Quarterly, Vol. 22, pp. 21, 23.

60 See generally Clague, Christopher et al (1996), Property and Contract Rights in Autocracies and Democracies (Munich Personal RePEc Archive), p. 51. 
Bad governance is one of the main impediments against secure property rights of the people. ${ }^{61}$ The FAO's guidelines of Good governance in land tenure and land administration ${ }^{62}$ present the potential impact of weak/bad governance in land administration. The manifestations of the potential impact include poverty and social exclusion; negative social behavior; environmental degradation; constraints on economic development; reduced public revenues; tenure insecurity; weak land and credit markets; and abuse of compulsory purchase.

According to United Nations Food and Agriculture Organization, there are three major symptoms of bad governance: state capture, administrative corruption, and lack of capacity. ${ }^{63}$ State capture occurs when public power is used to serve the interest of the powerful or those who are in power instead of the society on whose behalf they are supposed to act. ${ }^{64}$ The peculiar examples of administrative corruption are bribery, the employment of 'facilitators', theft, fraud, extortion and blackmail, nepotism and favoritism, and misconduct in public office. ${ }^{65}$ The common diagnoses of lack of capacity are lack of resources, lack of qualified or competent staff, and lack of institutional capacity, negligence, and mismanagement. ${ }^{66}$

Some of the causes of failures in governance are laws which may be poorly designed or implemented, inconsistent or outdated; inappropriate policies and procedures; complex institutional structures, where mandates are unclear, overlapping or duplicated; incorrect or inadequate information, especially spatial data, to support decision making; and inadequate civil service resources. ${ }^{67}$

${ }^{61}$ Wolfgang Kasper (2007), Secure Property Rights -The Foundation of Prosperity and Freedom in Africa (Paper presented at The Institutional Framework for Freedom in Africa, Nairobi/Kenya, February 2007), p. 12.

${ }^{62} \mathrm{FAO}$, supra note 25.

${ }^{63}$ Id., p.13-14.

${ }^{64}$ Ibid.

${ }^{65}$ Mark David Agrast et al (2012-13), The World Justice Project Rule of Law Index: 2012-2013 (WJP), p. 13.

${ }^{66} \mathrm{FAO}$, supra note 24, p. 17.

${ }^{67}$ Bell, supra note 17. 
Critical Gaps in Land Governance with Respect to the Land Registration System... 433

\section{Evaluating Land Registration Governance in Ethiopia: Towards a Conceptual Framework}

As highlighted in the preceding section, the concept of land management and its different components demonstrate various features of land governance and institutional capacity. This is because land governance involves processes related to the administration, development, and management of land. Some specific indicators or measures of these activities of good land governance are indicated in Land Governance Assessment Framework (LGAF) developed by Klaus Deininger et al. ${ }^{68}$ LGAF indicators are quite relevant to measure Ethiopia's land registration governance.

The LGAF has identified five key areas or indicators of good land governance, namely; (i) a legal, institutional, and policy framework; (ii) arrangements for land use planning and taxation; (iii) management of state land and proper application of expropriation with payment of fair compensation; (iv) public provision of land information; and (v) dispute resolution and management. ${ }^{69}$ As this study mainly focuses on land registration governance, the most relevant indicators are public provision of land information; and a legal, institutional, and policy framework. The following paragraphs will be devoted to the summary of several indicators relating to these broader indicators. ${ }^{70}$

With regard to public provision of land information four sub-indicators are identified. The first is completeness. Completeness entails that most records for privately held land registered in the registry are readily identifiable in maps in the registry or cadastre, relevant private and public encumbrances are recorded consistently and in a reliable fashion and can be verified at low cost by any interested party, the records in the registry can be searched by both right-holder name and parcel, copies or extracts of documents recording rights in property can be obtained by anyone who pays the necessary formal fee, if any, and copies or extracts of documents recording rights in property can generally be obtained within one day of request.

\footnotetext{
${ }^{68}$ See generally Klaus Deininger, Harris Selod, and Anthony Burns (2012), The Land Governance Assessment Framework Identifying and Monitoring Good Practice in the Land Sector).

${ }^{69} \mathrm{Id}, \mathrm{pp} .27-36$.

${ }^{70}$ For a concise presentation, see Id., pp. 40-45.
} 
The second is reliability. It ensures that registry information is up to date and sufficient to make meaningful inferences on ownership, there are meaningful and published service standards, and the registry actively monitors its performance against these standards. The third is costeffectiveness, accessibility, and sustainability. This indicator entails that land administration services are provided in a cost-effective manner; the cost for registering a property transfer is minimal compared to the property value; the total fees collected by the registry exceed the total registry operating costs; and there is significant investment in capital in the system to record rights in land so that the system is sustainable but still accessible by the poor. The fourth indicator is transparency which requires that fees are determined and collected in a transparent manner. Towards this end, clear schedule of fees for different services is publicly accessible, and receipts are issued for all transactions; and, mechanisms to detect and deal with illegal staff behavior exist in all registry offices, and all cases are promptly dealt with.

With regard to a legal, institutional, and policy framework, there are six indicators. The first indicator is recognition of a 'continuum' of rights. This indicator entails that the law recognizes a range of rights to fully or partially individualize ownership and use of land held by individuals as well as groups (including secondary rights as well as rights held by minorities and women), and clear regulations exist regarding the internal organization and legal representation of groups. Existing legal framework should recognize rights held by most of the rural and urban population, either through customary or statutory tenure regimes.

The second indicator is enforcement of land rights recognized by law (including secondary rights as well as rights of minorities and women). This indicator envisages that most communal lands have boundaries demarcated and surveyed or mapped and communal rights registered; most individual properties in rural and urban areas are formally registered where a high percentage of land registered to physical persons is registered in the name of women, either individually or jointly; common property under condominiums is recognized; when loss of rights occurs as a result of land use change not involving expropriation, compensation in cash or in kind is paid such that these people have comparable assets and can continue to maintain prior social and economic status.

The third indicator is existence of mechanisms for recognition of rights. This indicator entails that the formal definition and assignment of rights, and process of recording of rights, accords with actual practice or, where it does not, provides affordable avenues for establishing such consistency in a non-discriminatory manner. In addition, it entails the following:- 
Critical Gaps in Land Governance with Respect to the Land Registration System... 435

- non-documentary forms of evidence are used to obtain full recognition of claims to property only when other forms of evidence are not available;

- legislation exists to formally recognize long-term, unchallenged possession and applies to both public and private land, although different rules may apply;

- the costs for first-time sporadic registration for a typical urban property is low compared to the property value;

- there are no informal fees that need to be paid to effect first registration;

- the requirements for formalizing housing in urban areas are clear, straightforward, affordable, and implemented consistently in a transparent manner;

- there is a clear, practical process for the formal recognition of possession, and this process is implemented effectively, consistently, and transparently.

The fourth indicator is recognition of restrictions and responsibilities on rights. This indicator implies that land rights are not conditional on adherence to unrealistic standards. There is a series of regulations regarding urban and rural land use, ownership, and transferability that are for the most part justified on the basis of overall public interest and that are enforced.

The fifth indicator is clarity of institutional mandates. Institutional mandates concerning the regulation and management of the land sector would be clearly defined, duplication of responsibilities is avoided, and information is shared as needed at reasonable cost and is readily accessible. There would be a clear separation in the roles of policy formulation, implementation of policy through land management and administration, and the arbitration of any disputes that may arise as a result of implementation of policy.

The sixth and final indicator of good land governance is equity and non-discrimination in the decision-making process. Land policies would be formulated through a legitimate and equitable decision-making process that draws on inputs from consultation of all concerned. The legal framework is non-discriminatory, and institutions to enforce property rights are equally accessible to all. Towards this end, a comprehensive policy exists or can be inferred by the existing legislation. Cost of implementation of land policy is estimated, expected benefits are identified and compared to cost, and there are sufficient budget, resources, and institutional capacity for implementation. Land institutions report on land policy implementation in a 
regular, meaningful, and comprehensive way, with reports being publicly accessible.

The fulfilment or otherwise of these indicators and features could help us to see whether the land registration system is appropriately governed. The indicators are used to evaluate the land registration system of Ethiopia in the following section.

\section{Governance of the Land Registration System in Ethiopia}

\subsection{Legislative framework for the land registration system}

Ethiopia is a Federal state, currently, divided into 11 regional states and 2 city administrations. The Federal nature of governance in the country was introduced since 1991. Land management power is divided between the Federal Government and Regional Governments. ${ }^{71}$ The Federal Government 'shall enact laws for the utilization and conservation of land and other natural resources, historical sites and objects' ${ }^{72}$ On the other hand, States have the power 'to administer land and other natural resources in accordance with Federal laws ${ }^{73}$ which may include the power to enact for the same purpose. $^{74}$

At the federal level, the current applicable legislation is the Rural Land Administration and Land Use Proclamation No. 465/2005..$^{75}$ This legislation repealed and replaced the first law on land administration and use at the national level that became effective in $1997 .{ }^{76}$ The current Proclamation has only one provision on land registration, Article 6, under the heading of 'Rural land Measurement, Registration and Holding Certificate'.

${ }^{71}$ Constitution of the Federal Democratic Republic of Ethiopia Proclamation, 1995,

Proc. No 1/1995, Fed Neg Gaz, Year 1, No.1, Art. 50 (1) (hereinafter 'FDRE Constitution').

${ }^{72}$ I d., Art. 51(5).

${ }^{73}$ Id., Art. 52(2) (d).

74 See the Rural Land Administration and Land Use Proclamation, 2005, Proc. No, 456/2005, Fed. Neg. Gaz., Year 11, No.44, Art. 6 (hereinafter 'FRLAUP'), Art. 17 (1) and the Revised Rural Land Administration and Use Determination Proclamation, 2017, Proc. No 252/2017, Zikre Hig, Year 22, No 14, $4^{\text {th }}$ Paragraph (hereinafter 'ARLAUP'). Also see Abiy Chelkeba (2018), 'Competing Water Resource Demands in Ethiopia's Federal System: Infancy of the Law toward Integrated Management' Mizan Law Review, Vol. 12, No.2, pp. 241-242. He argues that state administration power includes legislation-making.

${ }^{75}$ FRLAUP, supra note 74, Art. 6.

${ }^{76}$ Federal Democratic Republic of Ethiopia Rural Land Administration Proclamation No. 89/1997. 
Critical Gaps in Land Governance with Respect to the Land Registration System... 437

Article 6(1) of Proclamation No. 465/2005 provides that size, land use and level of fertility of rural lands under private, communal, governmental and non-governmental organizations shall be measured as appropriate using cultural and modern measurement equipment. Sub-Article 2 stipulates that the land holdings shall be given cadastral maps showing their boundaries. And Sub-Article 3 provides that holding certificate shall be given that indicates the size of the land, land use type and cover, level of fertility and boarders, as well as the obligations and rights of the land-holder.

Sub-Article 4 states that where land is jointly held by husband and wife or by other persons, the holding certificate shall be prepared in the name of all the joint holders. Sub-Article 5 puts the key principle of land registration by stating that the information that describes the holder of rural land, the holders of the bordering lands, the types of use, and the rights and obligation of the holder thereof shall be registered in a database and kept by the competent authority. The provision also implies the possibility of registering land rights other than landholding by mentioning, under Sub-Article 6 that any rural land that is held through lease or rental shall be registered.

However, as we shall see later, these rules are too brief to address matters of land registration in Ethiopia. The Draft Rural Lands Administration and Use legislation has taken more than a decade for enactment. The Draft covers various matters as compared with the existing national land registration legislation. For example, it defines of the concepts of 'land registration', 'cadastre', 'parcel', 'parcel map', 'cadastral surveying', and 'registrar'. It also embodies rules on the management of lands under the holding of pastoralists and semi-pastoralists. Thus, the Draft makes it mandatory for regions to have a land administration and use law for communal lands used by pastoralists and semi-pastoralists; prohibits the alteration of these lands to private holding; makes it possible for owners of such lands to rent the land out to others; and permits the use of customary ways of land management, use and dispute resolution.

At regional level, all regions have adopted rural land administration laws. For instance, Amhara region issued the first law on rural land administration in 2000 following the issuance of the Federal proclamation. ${ }^{77}$ The region also issued the little known Land Administration and Land Use Policy in the same year. ${ }^{78}$ Then the region issued the Revised Rural Land Administration

\footnotetext{
${ }^{77}$ Amhara National Regional Rural Land Administration and Usage Determination Proclamation No. 46/2000.

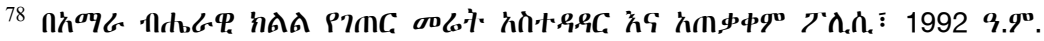


and Use Determination Proclamation No. 133/2006 that repealed the previous Proclamation No. 46/2000 and was in force until 2017. ${ }^{79}$ At the moment, the governing land law in the region is the ARLAUP. The Revised Rural Land Administration and Use System Implementation, Council of Regional Government Regulation No. $159 / 2018^{80}$ provides more details regarding the implementation of this Proclamation.

Article 33(1) of the Proclamation stipulates that a map is prepared for and issued to any rural land held in private, communally after measurement by traditional or modern means. Article 33(2) stipulates that a mark indicating the boundaries of each of these holdings must be made after being measured with different surveying materials. Article 34(1) stipulates that any measured rural landholding is registered in the land file which is established for this purpose. Article 35(1) states that a landholding certificate identifies the land, shall bear the name and photograph of the landholder, and shall be given to any rural landholder through the pertinent wereda rural land administration and use office. Specifically, Article 25(9) provides that communal landholders will be issued landholding certificate containing their names. According to Article 36(1), registration in ANRS is mandatory.

Other laws govern rural land administration, use, and land registration including in the regions of SNNP ${ }^{81}$, Oromia ${ }^{82}$, Tigray ${ }^{83}, \mathrm{Afar}^{84}$, $\mathrm{Somali}^{85}$, and Benishangul Gumuz ${ }^{86}$. With a few differences in some specific issues

${ }^{79}$ Revised (Amhara) Rural Land Administration and Use Determination Proclamation No $133 / 2006$.

${ }^{80}$ Revised Rural Land Administration and Use System Implementation, Council of Regional Government Regulation No. 159/2018 ('ANRS Regulation No. 159').

${ }^{81}$ Southern Nations, Nationalities and Peoples Land Administration and Use Proclamation No. 110/2007 and Rural Land Administration and Use Regulation No 66/2007.

${ }^{82}$ Oromia Rural Land Use and Administration Proclamation No. 130 /2007 and Oromia Rural Land Administration and Use Regulation No.151/2012.

83 Tigray National Regional State Rural Land Administration and Use Determination Proclamation No. 239/2014 and Tigray National Regional State Rural Land Administration and Use Regulation No. 85/2014.

${ }^{84}$ Afar National Regional State Rural Lands Administration and Use Proclamation No. 49/2009.

85 Somali Regional State Rural Lands Administration and Use Proclamation No. $128 / 2013$.

${ }^{86}$ Benishangul Gumuz Regional State Land Administration and Use Proclamation No 85/2010 and Benishangul Gumuz Regional State Land Administration and Use Proclamation Implementation Regulation 2010. 
Critical Gaps in Land Governance with Respect to the Land Registration System... 439

such as land rental period, all regional laws have similar content and objectives.

\subsection{Practical enforcement of the land registration system}

The enactment of land registration laws is not an end by itself because they need to be further seen in light of the process of their enforceability or implementation. Thus the operations and effectiveness of the institutions in charge of land registration in Ethiopia in enforcing the land registration system accompanied by adequate provision of tools to operate the land registration process need to be examined. To this end, three practical mechanisms: setting land registration in motion, caveats and updating are addressed in this section. They are used as practical indicators of good land governance in land registration systems in light of the factors (highlighted in Section 3) to be used as measures of good land registration governance in Ethiopia such as efficiency and transparency.

\subsubsection{Setting land registration in motion}

As indicated in Section 4.1, the Federal rural land administration law, FRLAUP, consists of only a single provision regarding registration of land. According to Article 6(1) \& (2), rural lands shall be measured, registered, and cadastral maps shall be given to land holdings. Land holding certificate that indicates size of the land, land use type and cover, level of fertility and borders, as well as the obligation and right of the holder shall be given to the land holder. ${ }^{87}$ Where land is jointly held by husband and wife or by other persons, the holding certificate shall be prepared in the name of all the joint holders. ${ }^{88}$ The landholding certificate is an evidence of the legally protected rights of the landholder; as such judges may not consider any documentary evidence or any witness before consulting the landholding certificate while there is one. ${ }^{89}$ The land holding information shall be registered in database and kept by the competent authority. ${ }^{90}$

The problem is that there are no rules regarding the process of application with respect to rural land registration. However, with respect to urban land, the law addresses such issues. Thus, the FULRP provides that any person claiming to have an interest on a land holding may apply for registration by filling the forms prepared by the registering institution for this purpose and

\footnotetext{
${ }^{87}$ FRLAUP, supra note 74, Art. 6 (3).

${ }^{88}$ Id, Art. 6(4).

${ }^{89}$ See ARLAUP, supra note 74, Art. 35(2).

${ }^{90}$ FRLAUP, supra note 74, Art. 6 (5).
} 
upon payment of the service fee. Such application shall clearly indicate the right, restriction and responsibility and shall be accompanied by supporting documents. $^{91}$

The applicant shall be granted a landholding certificate from the registering institution within 30 working days or at any time upon payment of service fee and penalty from the date of receiving the proof that entitles him for registration. ${ }^{92}$ Upon receiving applications for registration, the registering institution shall give the applicant the copy of the application with the seal of the institution, date, month, year, hour and minute written on the receipt of the application which shall constitute the basis for establishing the order of registration. ${ }^{93}$

Article 29 states that the registering institution shall verify that the applicant's request satisfies required formalities. Article 39 provides that notice of acceptance of registration shall be given to the applicant within five working days through the registered address of the landholder. Where an applicant is aggrieved by a decision of the registering institution that rejects a document presented by him during the adjudication process, he shall complain to a grievance handling body established for this purpose. ${ }^{94}$ Because of the dichotomised rural-urban land administration system in the country, rules found in FULRP are not directly applicable to rural lands. This creates gap in the governance of land registration in the country.

\subsubsection{System quality assurance and compliance mechanisms}

The other aspect of the enforcement of the land registration systems in the context of the good governance of the system is the provision of the mechanisms of ensuring the quality of the system and compliance with the system. By quality, we mean the integrity of the land registration; and compliance refers to the existing land rights, restrictions, and responsibilities. Some of the most important mechanisms whereby land registration systems achieve these purposes are caveats, updating, and payment of compensation.

\footnotetext{
${ }^{91}$ FULRP, supra note 11, Art. 27 (1) \& (2).

${ }^{92}$ Id., Art. 27 sub-arts. $3 \& 4$.

${ }^{93}$ Id., Art. 28 (1).

${ }^{94}$ Id., Art. 29(2).
} 
Critical Gaps in Land Governance with Respect to the Land Registration System... 441

a) Caveats

Caveats, cautions or precautions are used to protect land interests both before and after registration. Caveats could be considered as the principal effective methods of gaining protection for unregistered interests. ${ }^{95}$ In Ethiopia, caveat provisions are scarce. The Federal and regional urban and rural land laws do not have caveat rules. Exceptions to this are found in the ANRS rural land laws.

These laws state that an aggrieved party may submit an objection or a complaint to a registering institution in writing within one month starting from the date on which the information was registered pending the final or complete entry of the information into the rural land record as a complete one. ${ }^{96}$ The institution is duty-bound to provide a written response within one month from the date on which such complaint was submitted thereto. ${ }^{97}$ The rules do not mention whether the institution shall let the registered proprietor know of such objection. Neither do they mention how the potential objector would be communicated. This scarcity of caveat provisions in Ethiopia creates gap in the governance of the land registration system.

In advanced land registration systems, caveats are given wide attention. Thus, in the Victoria (one of the states in Australia), there are three types of caveats -caveats against the bringing of land under the registration system; caveats against dealing with land, and caveats against granting title by adverse possession. ${ }^{98}$ The Victorian land registration law has detailed rules on these. ${ }^{99}$ With respect to the first type, following notice given by the Registrar prior to the creation of an ordinary folio or a provisional folio, any person claiming an estate or interest in the land in question may, before the creation of the folio for that land or the removal of the warning, lodge a caveat in an appropriate approved form forbidding the creation of the folio. ${ }^{100}$ The Registrar must then notify the person who has applied for registration. ${ }^{101}$ The Registrar must not proceed with the creation of the folio

95 See generally Douglas Whalan (1982), The Torrens System in Australia (The Law Book Company Limited), pp. 223-268.

${ }^{96}$ ARLAUP, supra note 74, Art. 43 (3) cum. ANRS Regulation No.159, supra note 80, Art. 27.

${ }^{97}$ ANRS Regulation No.159, supra note 80, Art. 27(2).

${ }^{98}$ Whalan, supra note 95 , pp. 223-68.

99 Transfer of Land Act 1958 (Vic) ('TLA').

${ }^{100}$ Id., s 26R(1).

${ }^{101}$ Id., s 26R(3)(a). 
until the caveat has been withdrawn or has lapsed, or a judgment or order in the matter has been obtained from a court as final settlement. ${ }^{102}$

Caveats against dealing with land may be used in two situations. Firstly, a caveat might be used by a person claiming an estate or interest in land which is the subject of a transaction to forbid the registration of any person as transferee or proprietor. ${ }^{103}$ Following the caveat, 'the Registrar shall give to the registered proprietor of the estate or interest concerned notice of the caveat together with a copy of the caveat or of such particulars thereof as the Registrar deems material'. ${ }^{104}$ The Registrar must duly consider the interest of the caveator and the registered proprietor and make all necessary amendments in the Register. ${ }^{105}$

Secondly, a caveat against dealing with land may be entered by the Registrar. Thus, the Act provides that the Registrar may record a caveat on behalf of the Crown, a minor or a person of unsound mind for the prevention of any fraud or improper dealing. ${ }^{106}$ Third, in Victoria caveats may be used to protect against title by adverse possession. The Transfer of Land Act (TLA) provides that '[a] person claiming any estate or interest in the land in respect of which any such application [for adverse possession] is made may before the granting of the application lodge a caveat in an appropriate approved form with the Registrar forbidding the granting thereof'. ${ }^{107}$

In Sweden, before accepting the application for registration of land, the land registration authority is required to make all the necessary precautions. Thus, if there is reason to suppose that the acquisition invoked by the applicant is invalid or cannot be asserted or that the measure requested would otherwise encroach on the rights of another party, the land registration authority shall give the person whose rights are likely to be affected the opportunity of expressing his interest in writing; this mechanism is called communication. ${ }^{108}$ The land registration authority shall then settle the matter itself or refer it to judicial settlement. ${ }^{109}$

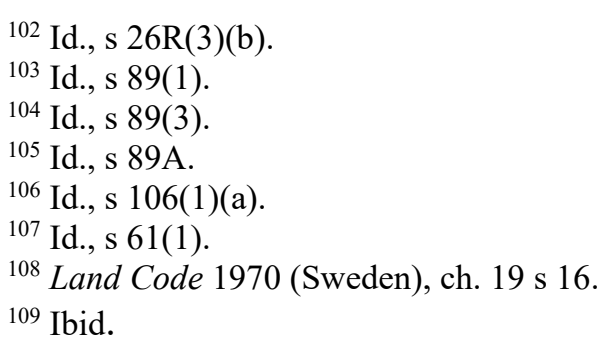


Critical Gaps in Land Governance with Respect to the Land Registration System... 443

b) Updating

Updating is another mechanism which the government should use in order to secure the quality and benefits of the land registration system and thereby maximise the practice of good land governance. To make the system sustainable and viable, all the necessary land information that is different from the initial register data must be amended, corrected, or deleted following any appropriate activity.

The Federal rural land registration law does not have updating rules which creates huge gap in the governance of the land registration system. However, the urban land registration law has updating rules. Article 38 of the FRLAUP provides that the registering institution shall update the landholding information recorded in the register of legal cadastre. Further, Art. 45 provides for correction and cancellation of registration. Sub-Art. 1 provides that any entry in a register may be corrected based on the request of the person who caused its registration, by the judgment of a court or an appropriate organ or by the agreement of persons interested in the matter. According to Sub-Article 2, where the cancellation of registration is ordered by court or appropriate organ, the rights, restrictions and responsibilities entered in the register shall be cancelled therefrom. And, as stipulated under Sub-Art. 3, a registered right, restriction, or responsibility may be cancelled by the decision of the registering institution of its own motion only where the said right, restriction, and responsibility was created for a definite period and such period has lapsed.

ANRS land laws also have updating provisions. They state that the land registration document must be updated following changes with respect to the landholder or farm or both. ${ }^{110}$ One of the powers and functions of the Wereda rural land administration and use office is the power to design a system whereby individuals transfer their holding rights through succession, rent, donation or exchange and update by periodically registering changes caused by these transactions. ${ }^{111}$ Whosoever wishes that the rural land registration information be varied, updated or the holding thereof be transferred may, having attached his document thereto, submit a request in writing to the pertinent Kebelle or Woreda rural land administration and use office. ${ }^{112}$

\footnotetext{
${ }^{110}$ ARLAUP, supra note 74, Art. 43(1); ANRS Regulation No.159, supra note 80, Arts. 29 and 32.

111 ARLAUP, supra note 74, Art. 48(5).

112 ANRS Regulation No.159, supra note 80, Art. 29(1).
} 
A notice describing such fact ought to be posted at the Kebelle land administration office, the Kebelle rural land administration and use office as well as any other suitable place thereof for the period of 15 consecutive days so that an opponent or party contending for a right would appear thereof. ${ }^{113}$ If a request for updating is accepted, the registrar has a responsibility to correct the holding registration data as fast as possible. ${ }^{114}$ The function of updating the rural land registration data is carried out by the Kebelle and Wereda land administration and use Committees. ${ }^{115}$

However, the law does not put strict obligations on the registrar to discharge its responsibility of registration and updating. For instance, it provides that "when harm [occurs] on any person due to the fault of the registrar, the government body that committed the fault shall be accountable by both civil and criminal responsibility'. ${ }^{116}$ This provision refers to fault in the process of registration. But, in practice, most problems occur due to the failure of the registration offices to keep register of updates on landholding. There is also no awareness on the part of land holders to submit application for registration of updated land holding.

In general, the updating mechanism may be carried out according to the power given to the Registrar upon his/her initiation, upon the application of an interested proprietor or upon court order. ${ }^{117}$

\section{c) Compensation}

The third mechanism whereby the land registration institutions enhance the quality of the land registration system and land governance is through provision of compensation during error or other reasons. Internationally, the Torrens system has a state-guaranteed system of compensation called Assurance Fund or Consolidated Fund based on the insurance principle. ${ }^{118}$ The Swedish system also provides for the payment of compensation. ${ }^{119}$ In Ethiopia, the Federal rural land registration law does not have compensation rules. On the other hand, Article 40 of FULRP provides that the registering institution shall be liable for damage caused to third parties who acted in good faith relying on the proof of registration of right, restriction or

\footnotetext{
${ }^{113}$ Id., Art. 29(2).

114 ARLAUP, supra note 74, Art. 43(1) \& (5).

${ }^{115}$ Id., Art.43 (1) \& (2).

${ }^{116}$ Id., Art. 34 (6).

${ }^{117}$ Although the Ethiopian pertinent legislation is not detailed in this aspect, other countries' laws have clear provisions. See eg TLA, ss 26N(9), 103(1), 103 (1AA).

${ }^{118}$ Id., ss 107-111).

${ }^{119}$ See Land Code 1970 (Sweden), ch 19 s 37; ch 18 s 5.
} 
Critical Gaps in Land Governance with Respect to the Land Registration System... 445

responsibility on a registered landholding. The regions may establish security fund to discharge such liability. ${ }^{120}$ It provides that part of the security fund may be utilized for public developmental purposes as may be determined by the regions. The provision on utilisation of the security fund for other purposes is detrimental to the governance of the land registration system.

ARLAUP similarly provides that when harm occurs on any person due to the fault of the registrar, the government body that committed the fault shall be accountable to pay compensation for the victim. ${ }^{121}$ But no provision exists for the creation of any compensation fund to be directly guaranteed by the state authorities.

Indeed, the laws at federal and regional state levels show adequate effort with regard to the land registration system. There are also attempts to establish the necessary legal and institutional mechanism in order to enforce the land registration system. But the Ethiopian land registration system has serious challenges with regard to good land governance as discussed in the following section.

\section{Salient Land Governance Gaps in Ethiopia's Land Registration System}

The first key source of bad land governance in Ethiopia is the existence of separate land management and registration institutions for rural lands and urban lands. I argue that Ethiopia is the only country with this model of land registration institutionalization. At the Federal level, the highest authority for rural land administration and use is vested in the Federal Ministry of Agriculture. It has the responsibility to implement the Federal rural land administration and use laws by providing the necessary professional support, coordinate the competent authorities, initiate development of new policy ideas and the amendment of the existing policy, conduct monitoring and evaluation, and create the system for the exchange of information among regions and the Federal Government. ${ }^{122}$

\footnotetext{
${ }^{120}$ FULRP, supra note 11, Art. 41(1).

${ }^{121}$ ARLAUP, supra note 74, Art. 34(6) and (7).

${ }^{122}$ Id., Art. 16.
} 
Towards this end, the Rural Land Administration and Utility Directorate ('RLAUD') was established in 2009 under the Ministry of Agriculture. ${ }^{123}$ It has three departments, namely, the registration of land, land use plan development, and other modern technology implementations. The RLAUD aspires to provide technical help for the regional offices such as training, developing projects, soliciting funds to implement modern registration of land and certification processes, and researching law and policy matters concerning land administration and use. ${ }^{124}$

As indicated earlier, the regions have the power to administer land and other natural resources. Regions are required to 'establish institutions at all levels that shall implement rural land administration and land use systems, and shall strengthen the institutions already established'. ${ }^{125}$ Bureaux are established in each region for this purpose. There are four hierarchical levels of land administration, namely, region/head office or Bureau, Zone Office, Woreda Office and Kebelle office. Each has its own functions.

With regard to urban land, there are distinct land administration and registration institutions. The responsible Federal ministry is the Ministry of Urban Development and Housing. Article 49 of FULRP provides the functions of the Ministry. Accordingly, it shall have the powers and duties to follow up and ensure the proper implementation of the urban land holding Proclamation and regulations, directives and standards issued thereunder, to provide technical support and training assistance to regions, and to serve as a national information resource center on urban land registration and related information. ${ }^{126}$ A separate body, the Federal Urban Real Property Registration and Information Agency ('FURPRIA'), was established at the Federal level to supervise urban landholding and information registration institutions. ${ }^{127}$ The registering institutions are established under FURPRIA, being accountable to it, to undertake registration of urban land and immovable property information. ${ }^{128}$

${ }^{123}$ Federal Democratic Republic of Ethiopia - Options for strengthening land administration (English,Amharic). Washington, D.C.: World Bank Group. https://documents1.worldbank.org/curated/en/428401468252886112/pdf/616310ES W0AMHA0DMINISTRATION0REPORT.pdf. Accessed on 28 May 2021.

${ }^{124}$ Daniel Behailu (2015), Transfer of Land Rights in Ethiopia: Towards a Sustainable Policy Framework (eleven international publishing, Hague, Netherlands), p.90.

${ }^{125}$ FRLAUP, supra note 74, Art 17(2).

${ }^{126}$ FULRP, supra note 11, Art. 49.

127 Id., Art. 2(19).

${ }^{128}$ Id., Art. 2(20). 
Critical Gaps in Land Governance with Respect to the Land Registration System... 447

At the regional level too, each region shall establish an equivalent supervising institution to FURPRIA as well as landholding registration and information institution at urban level for the implementation of the urban land holding and registration legislations. ${ }^{129}$ The regions have also the duty to ensure the proper enforcement of regulations and directives which they may issue in accordance with the Federal legislative framework. ${ }^{130}$ Urban administrations are in charge of urban landholding registration and information. They must serve as the sole information producing centers for legal cadastre registration and they have the power to own, organize and manage legal cadastre data. ${ }^{131}$ They must also forward registered information to the appropriate regional supervising body and to the FURPRIA. ${ }^{132}$

The existence of separate institutional and legal framework for rural and urban lands has led to the establishment of fragmented institutions for land administration and registration. For instance, in Bahir Dar a separate land holding and registration office is established for rural lands in the city within the Bahir Dar City Administration. The urban territory is steadily expanding and as a result it encloses rural land holdings. Then the question of which land management institution and which land law is going to regulate this newly enclosed rural land becomes a question. The urban land administration and the rural land administration offices also compete with each other on issues such as entitlement to compensation in the case of expropriated land.

As Fitzpatrick notes, in circumstances of institutional pluralist relations, state agencies 'are more likely to pursue their own interests by pandering to a constituency, increasing tax revenues, or implementing a rent-seeking development agenda'. ${ }^{133}$ The land holders also consume much time finding and choosing between the institutions to receive land registration service especially relating to obtaining land holding information to submit to courts during land dispute resolution. These circumstances would ultimately give birth to disputes between land holders and land management institutions which proves bad governance.

\footnotetext{
${ }^{129}$ Id., Art. 50(1).

${ }^{130}$ Id., Art. 50(2).

${ }^{131}$ Id., Art. 51(1) \& (3).

132 Id., Art 51(2).

${ }^{133}$ Fitzpatrick, supra note 32, p.1041 (citation omitted).
} 
The rural-urban land administration dichotomy also produces inconsistency in ideas and concepts regarding land rights. For instance, the urban land administration is mainly based on 'leasehold' whereas the rural land administration considers a specific land tenure as 'landholding'. Leasehold was introduced by the Urban Lands Lease Holding Proclamation No.80/1993. ${ }^{134}$ This Proclamation was repealed and replaced consecutively by two laws. ${ }^{135}$ The terminological difference between the 'land-holding' tenure of rural lands and the 'leasehold' tenure of urban lands is not clear enough. This is especially because FULRP specifically considers urban leasehold as a type of 'land-holding' of urban lands. ${ }^{136}$ In addition, leasehold is one type of land tenure in rural areas too. This application of inconsistent language with respect to rural and urban lands becomes a source of bad land governance.

Third, the rural-urban land administration dichotomy opens a wide room for different application of rules on land registration enforcement. As discussed earlier, the rural and urban land administration laws have different scope with respect to addressing these functions of land management and governance. In general, land registration legislation in Ethiopia is dispersed, undetailed, incomprehensive, unstable, incongruent and incoherent. For instance, the rural land administration legislation, unlike urban land administration legislation, does not regulate how registration applications are submitted to the land registration offices when there is one or the form of transaction such as sale, lease, gift, inheritance, land exchange, and mortgage that induces updating. Everything is done customarily rather than based on prescribed rules. That has caused many disputes which have engulfed the courts.

In one case still pending in a woreda court, ${ }^{137}$ the plaintiff sued the defendant in order to get back the land which she believes is hers acquired through inheritance (now unlawfully possessed for long time). The defendant responded that he got the land in dispute from another person who, consequently, was made to be a party to the case. The defendant argued that he got the land from the guarantor through land to land exchange but the exchange contract was done orally or traditionally and it was not

\footnotetext{
${ }^{134}$ Urban Lands Lease Holding Proclamation No.80/199

135 Re-enactment of Urban Lands Lease Holding Proclamation No. 272/2002; Urban Lands Lease Holding Proclamation No 721/2011.

${ }^{136}$ FULRP, supra note 11, Art. 2 (3).

${ }^{137}$ Mamey Worke vs. Dessie Chalachew, South Achefer Worea Court, File No. 244576, 2020 .
} 
registered and authenticated. The land registration offices usually focus on initial registration, and as stated earlier, legislation on updating is inadequate.

Similarly, the Federal-State land governance dichotomy has imposed its own challenges for sound land governance in the country. For instance, the proper meaning of the constitutional provisions regarding the Federal-State sharing of power with regard to land management are not easy to understand. First, when the rule says 'utilization and conservation' does it include 'administration', 'use' and 'registration'? If the answer is in the affirmative, and, as we indicated, if the regional states can enact laws, what is the difference between the lawmaking power of the federal government and the regional states? Second, if the answer is in the negative, does it mean that the federal government may not enact laws for the administration and use of land and is it the case that this power is left to the regional states?

Addressing these issues needs to consider principles such as 'coherence' and 'clarity'. But first, we need to recall that in practice the Federal Government is making legislation both for the 'conservation', 'utilisation' and 'administration and use' of land and other natural resources. ${ }^{138}$ A typical example for this is the Federal Proclamation for the Rural Land Administration and Use Proclamation No. 456/2005 that is enacted for the administration and use of land including the 'conservation'. Regional states are also making legislation for land administration and use under claiming that they are constitutionally empowered 'to administer' land and other natural resources.

The FDRE Constitution vests power in the federal government to enact legislation for the proper management, administration, conservation and utilisation of land. In particular, this refers to the enactment of legislation that creates land rights, restrictions and obligations. The creation of the land rights, restrictions and responsibilities apparently envisages the subsequent acts of enforcing or implementing or administering those clearly defined property interests.

A national legislative framework is expected to create sustainable land administration and cadastral system where there is uniformity, consistency, coherence, equality, fairness and rationality in the system. This will also enhance good governance in land administration by reducing the chances of existence of discriminatory property rights in the country.

${ }^{138}$ It seems that the words 'utilization' and 'use' have the same meaning as used in the FDRE Constitution and other national and regional legislations. 
We can illustrate this by mentioning three examples. First, we can raise duration of property use rights. Duration is different across regions such as differences in the duration for lease and rental contracts and so on. ${ }^{139}$ As a second example, we can raise the use of the term 'possession' and 'landholding'. Oromia region uses the term 'possession' while other regions and the national legislation use the word 'landholding'. ${ }^{140}$ But the former concept has another meaning in the Ethiopian Civil Code. ${ }^{141}$ Possession means the actual control which a person exercises over property or land. But 'landholding' right refers to various rights and interests on land where possession is just one of them. ${ }^{142}$ As a third case of incoherence, we can mention that mortgage of rural land is not clearly mentioned in the national land registration legislation and in many regions; but in Amhara region mortgage is clearly permitted. ${ }^{143}$

These problems are the result of lack of an overarching national legislative and land policy framework creating property rights, restrictions and responsibilities. As Williamson correctly states, land policy principles are one of the best practices to establish a good and sustainable land registration governance system and enhance the values of completeness, uniformity, consistency, coherence, equality, fairness and rationality in the system. ${ }^{144}$ In the meantime, the federal government needs to maintain its task of creating uniform property rights, restrictions and responsibilities whereas regions should focus on enforcing these property interests.

Likewise, it is very important to ensure that the urban land administration follows this course. It is to be noted that the Federal urban land holding and registration legislation enacts all rights, restrictions and responsibilities ${ }^{145}$ whereas the regional governments are vested with the power to ensure the proper implementation of this legislation which does not include enacting

139 For example, according to Article 10(2) of the Oromia Rural Land Use and Administration Proclamation No. 130 /2007, "duration of the agreement shall not be more than three years for those who apply traditional farming, and fifteen years for mechanized farming". In Amhara region, the maximum lease year of rural land for agricultural investment is 30 years. ARLAUP, supra note 67, Art. 22(6).

${ }^{140}$ Oromia Rural Land Use and Administration Proclamation No. 130 /2007, Art 2(7).

${ }^{141}$ See Ethiopian Civil Code (1960), Arts. 1140-1150.

${ }^{142}$ FRLAUP, supra note 74, Art. 2 (4).

${ }^{143}$ ARLAUP, supra note 74, Art.19.

${ }^{144}$ Ian P Williamson, 'Land Administration "Best Practice" Providing the Infrastructure for Land Policy Implementation' (2001) 18(4) Land Use Policy 297, 303-5.

145 See generally FULRP, supra note 11. 
Critical Gaps in Land Governance with Respect to the Land Registration System... 451

legislation in the pretext of administration of urban lands within the regions. $^{146}$

The other problem relates to objectives. Unlike Victoria and Sweden, Ethiopia's laws on the land registration system do not express their objectives clearly and directly. This is true starting from the cadastral system legislation. The first national law on land administration and use, i.e., the Federal Rural Land Administration Proclamation became effective in 1997. ${ }^{147}$ Regional states adopted related legislations subsequently or almost around the same time. However, none of the provisions in these laws mentioned the term 'land registration' or its equivalent.

For example, the first Land Administration Proclamation No. 46/2000 of the Amhara regional merely stated that 'so long as the land users utilize the land according to the established rules, this proclamation assures and secures their holding and use rights' and that tenure security enables 'the peasant to work for sustainable development'. ${ }^{148}$ The term 'tenure security' seemed to have implied land registration, and carrying out land registration on this basis is arguably not wrong. Therefore, although these first generation land laws did not clearly address land registration, the practice of land certification began soon after their adoption. ${ }^{149}$ That means, actually, these laws led to the issuance of a 'Primary Book of Land Holding' to the land holders merely tacitly.

As indicated in the introduction of this article, the issuance of land certificates began in the regional states at different periods since 1998. And in due course, the idea of land registration came to be relatively clearly expressed in what can be referred to as the second generation land registration legislations. Although the land certification and registration process in Ethiopia initially lacked clear focus, direction and objective, there have been improvements. In spite of such improvements, however there are various gaps which include scarcity of rules of application for land registration, updating, and payment of compensation. These gaps have caused negative impact on the governance of land registration in Ethiopia.

\footnotetext{
146 See Id., Art. 50.

${ }^{147}$ Federal Land Administration Proclamation No. 89/1997, supra note 76.

${ }^{148}$ Amhara Land Proclamation No. 46/2000, supra note 77, Art. 6(3).

149 In Amhara region, the ANRS Rural Land Administration and Use Determination Proclamation No. 133/2006 and ARLAUP were adopted subsequently which directly address the practice of land registration, and legislation is improving in the region from time to time. But at federal level legislation improvement is relatively slow.
} 


\section{Concluding Remarks}

Good land governance plays a critical role in the success of land registration systems and in order for the systems to bring full benefits to society in terms of sustainable development. Ethiopia's land registration governance features a few key gaps which posit serious challenges in the success of its land registration system. First, the structural issue of urban-rural dichotomy of land administration has been a problem. This in turn has resulted in bifurcated land management legislations and institutions for urban and rural lands. Second, the absence of clear practice regarding division of the federalstate land management power has been a problem. At the level of proclamation (and to some extent at the level of constitution), there is the practical problem of distinguishing and interpreting 'legislating' and 'administering' powers with respect to the utilization, conservation, and development of the country's land resource.

These two problems have resulted in the prevalence of incomplete and varied legislative rules, and inconsistent understanding and implementation of existing rules. Besides, they have resulted in fragmented enforcement institutions with inconsistent, incoherent, and incompetent practices in the handling of land registration in all levels. Thus, these gaps in land governance are clearly observed while commencing the land registration following any land related transaction such as will, donation, rent, mortgage, in the addressing of caveats and compensation instruments and in updating.

As a result, almost every measure of good land governance in Ethiopia especially with respect to the land registration system can be contested. It is thus essential and timely that Ethiopia works towards enhancing its land registration governance by the provision of, among other things, adequate legislative and policy framework and working standards, land registration institutional machinery and efficient enforcement of the system through laying down appropriate land registration procedures, quality control mechanisms and judicial enforcement mechanisms. 
Critical Gaps in Land Governance with Respect to the Land Registration System... 453

\section{Cited References}

Acemoglu, D. and Robinson, J. A. (2012). Why Nations Fail: the Origins of Power, Prosperity, and Poverty (Crown Business New York, 1st ed)

Agrast, Mark David et al (2012-13). The World Justice Project Rule of Law Index: 2012-2013 (WJP)

Bell, Keith C. (2007). Good Governance in Land Administration (FIG Working Week Hong Kong, China SAR, May 13-17, 2007)

Berhanu Adenew and Fayera Abdi (2005). Land Registration in Amhara Region, Ethiopia (Research Report 3, Central Research Department of the UK's Department for International Development)

Burns, T \& Dalrymple, K (2008). Conceptual Framework for Governance in Land Administration (FIG Working Week in Stockholm, Sweden)

Byamugisha, Frank (2016), Transforming Africa's Agriculture Securing Land Tenure and Easing Access to Land, Background Paper for African Transformation Report 16 (Joint research between African Center for Economic Transformation (ACET) and Japan International Cooperation Agency Research institute (JICA-RI)

Clague, Christopher et al (1996). Property and Contract Rights in Autocracies and Democracies (Munich Personal RePEc Archive)

Daniel Behailu (2015). Transfer of Land Rights in Ethiopia: Towards a Sustainable Policy Framework (eleven international publishing, Hague, Netherlands)

De Soto, Hernando (2000). The Mystery of Capital: Why Capitalism Triumphs in the West and Fails Everywhere else (Black Swan)

Deininger, K. \& Feder, G. (2009), 'Land Registration, Governance, and Development: Evidence and Implications for Policy' The World Bank Research Observer, Vol. 24

Deininger, Klaus et al (2012). The Land Governance Assessment Framework Identifying and Monitoring Good Practice in the Land Sector)

Enemark, S. (2009). Facing the Global Challenges: the Importance of Land Governance and the Significance of the Cadastre (Proceedings of FIG Commission 7 One-day International Open Symposium "Progressing Towards u-Cadastre")

Enemark, Stig (2005). Supporting Capacity Development for Sustainable Land Administration Infrastructures (Paper presented at the Eighth United Nations Regional Cartographic Conference for the Americas (UNRCCA), New York)

Enemark, Stig (2005). Understanding the Land Management Paradigm (FIG Com 7 Symposium on Innovative Technologies for Land Administration 19 - 25 June, Madison, Wisconsin, USA)

Fuller, Lon (1969). The Morality of Law, Rev. Ed. (New Haven: Yale University Press)

Gizachew Abebe et al (2015). Implementation Challenges of the Rural Land Administration System in Ethiopia: Issues for Land Certification and the Information System (Paper prepared for presentation at the 2015 World Bank Conference on Land and Poverty, Washington DC, March 23-27, 2015)

Hull, S. \& Whittal J. (2013). 'Good e-Governance and Cadastral Innovation: In Pursuit of a Definition of e-Cadastral Systems', South African Journal of Geomatics, 2(4) 
Joireman, Sandra F (2011). Where There is No Government: Enforcing Property Rights in Common Law Africa (Oxford University Press)

Kasper, Wolfgang (2007). Secure Property Rights -The Foundation of Prosperity and Freedom in Africa (Paper presented at The Institutional Framework for Freedom in Africa, Nairobi/Kenya, February 2007)

Kaufmann, J. and Steudler, D. (1998). Cadastre 2014 - A Vision for a Future Cadastral System ( FIG Commission 7, Switzerland); FIG (1995)

Kjellson, Bengt (2002), What Do Americans Pay for not having a Public Land Rights Information System? (Paper presented at FIG Congress, Washington D C)

Krznaric, Roman (2006). 'The Limits on Pro-poor Agricultural Trade in Guatemala: Land, Labour and Political Power' Journal of Human Development, Vol 7

Larmour, Peter (2002). 'Policy Transfer and Reversal: Customary Land Registration from Africa to Melanesia' Public Administration \& Development, Vol 22

Manji, Ambreena (2006). The Politics of Land Reform in Africa: From Communal Tenure to Free Markets (Zed Books)

Melkamu Belachew (2015). Modelling Legislation for a Sustainable Cadastral System (PhD thesis, University of Melbourne, Melbourne Law School)

Muchomba, Felix M. (2017). 'Women's Land Tenure Security and Household Human Capital: Evidence from Ethiopia's Land Certification', World Dev., Vol.98

Palmer, Robin (2007). Literature Review of Governance and Secure Access to Land

Park, Malcolm (2003). The Effect of Adverse Possession on Part of a Registered Title Land Parcel (University of Melbourne, PhD Thesis)

Persha, Lauren et al (2017). Assessing the Impact of Second-Level Land Certification in Ethiopia (Paper prepared for presentation at the "2017 World Bank Conference on Land and Poverty" The World Bank-Washington DC, March 20-24, 2017)

Reimers, Milt (2009-2010). "Stuck in No Man's Land": How Developing Countries Can Allocate Property Rights as a Means to Improve Their Citizens' Welfare and Grow Their Economies' Loyola Journal of Public Interest Law, Vol.11

Shewakena Aytenfisu Abab (2007). An Assessment of Rural Land Registration and Land Information System in Amhara Region, Ethiopia: a Land Administration Perspective (unpublished MSc thesis, the Royal Institute of Technology, Department of Real estate Planning and Land Law, Sweden)

Solomon Dargie Chekole et al (2020). 'An Evaluation Framework for Urban Cadastral System Policy in Ethiopia', Land, Vol.9, Issue 60

Wadhwa, DC (2002). "Guaranteeing Title to Land" Economic and Political Weekly, Vol.37

Whalan, Douglas (1982). The Torrens System in Australia (The Law Book Company Limited)

Williamson, I. P. (2001). "Land Administration "Best Practice" Providing the Infrastructure for Land Policy Implementation' 18(4) Land Use Policy 297

Zakout, W et al (2007). Good Governance in Land Administration: Principles and Good Practices (World Bank and FAO). 